$\begin{array}{ll}\text { Abstracta Iranica } & \begin{array}{l}\text { Abstracta Iranica } \\ \text { Revue bibliographique pour le domaine irano-aryen }\end{array} \\ & \text { Volume } \mathbf{2 6} \mid \mathbf{2 0 0 5} \\ & \text { Comptes rendus des publications de } \mathbf{2 0 0 3}\end{array}$

\title{
«Les livres des Sogdiens ». Studia Iranica, 32 (2003-1), pp. 127-136.
}

Rédaction

\section{(2) OpenEdition}

Édition électronique

URL : http://journals.openedition.org/abstractairanica/3103

ISSN : 1961-960X

Éditeur :

CNRS (UMR 7528 Mondes iraniens et indiens), Éditions de l'IFRI

Édition imprimée

Date de publication : 15 mai 2005

ISSN : 0240-8910

\section{Référence électronique}

Rédaction, « «Les livres des Sogdiens ». Studia Iranica, 32 (2003-1), pp. 127-136. », Abstracta Iranica [En ligne], Volume 26 | 2005, document 71, mis en ligne le 15 décembre 2005, consulté le 25 septembre 2020. URL : http://journals.openedition.org/abstractairanica/3103

Ce document a été généré automatiquement le 25 septembre 2020.

Tous droits réservés 


\section{« Les livres des Sogdiens ». Studia Iranica, 32 (2003-1), pp. 127-136.}

\section{Rédaction}

1 À partir d'une nouvelle découverte de Pendjikent, montrant un livre de grande taille promené en procession au $8^{\mathrm{e}} \mathrm{s}$., et d'un texte chinois, les auteurs montrent l'existence probable en Sogdiane de codices monumentaux, sans doute tout ou partie de l'Avesta. Voir sur ce point la réponse de B. Marshak (c.r. $\left.n^{\circ} 78\right)$.

\section{INDEX}

Thèmes : 3.1. Est de l'Iran

Keywords : Codex, sogdian, Avesta

nompropre Sogdien

\section{AUTEURS}

\section{RÉDACTION}

Directeur de la revue et secrétariats (Paris et Téhéran) 